\title{
PEMBINAAN DAN PENGGUNAAN BAHASA DALAM MENULIS KARYA ILMIAH PADA EKSTRAKURIKULER KARYA ILMIAH REMAJA (KIR) DI SMA LABORATORIUM UNDIKSHA
}

\author{
Ni Nyoman Dewi Narayukti ${ }^{1}$, I Wayan Artika², I Wayan Rasna ${ }^{3}$ \\ Jurusan Pendidikan Bahasa dan Sastra Indonesia, Fakultas Bahasa dan Seni \\ Universitas Pendidikan Ganesha \\ Singaraja, Indonesia \\ e-mail: dewinarayukti@gmail.com¹, wayan.artika@undiksha.ac.id², \\ wayanrasna@ymail.com³
}

\begin{abstract}
ABSTRAK
Penelitian ini bertujuan mengkaji (1) proses pembinaan menulis karya ilmiah dalam ekstrakurikuler karya ilmiah remaja (KIR) di SMA Laboratorium Undiksha, (2) penggunaan bahasa dalam karya ilmiah siswa pada ekstrakurikuler karya ilmiah remaja (KIR) di SMA Laboratorium Undiksha, dan (3) keterkaitan pembinaan menulis karya ilmiah dengan penggunaan bahasa dalam karya ilmiah siswa pada ekstrakurikuler karya ilmiah remaja (KIR) di SMA Laboratorium Undiksha. Penelitian ini menggunakan ancangan deskriptif kualitatif. Data dikumpulkan dengan metode observasi, wawancara, dan dokumentasi. Hasil penelitian ini menunjukkan (1) proses pembinaan menulis karya ilmiah pada ekstrakurikuler karya ilmiah remaja (KIR) di SMA Laboratorium Undiksha, yang meliputi (a) pemberian materi dasar karya ilmiah, (b) berlatih menulis karya ilmah, dan (c) berlatih presentasi. (2) Ditemukan kesalahan penggunaan bahasa dalam karya ilmiah siswa, yakni kesalahan (a) ejaan dan (b) tata kalimat. (3) Penggunaan bahasa karya ilmiah siswa berkaitan dengan pembinaan yang diberikan oleh pembina.
\end{abstract}

Kata Kunci:pembinaan, karya ilmiah remaja (KIR)

\begin{abstract}
This study aims to review (1) the process of writing scientific in extracurricular KIR at Undiksha Laboratory High School, (2) the use of language in students scientific work on extracurricular KIR at Undiksha Laboratory High School, and (3) the correlation of scientific writing with the use of language in students scientific work on extracurricular KIR at Undiksha Laboratory High School. This research was descriptive qualitative approach. The data were collected by observation, interview, and documentation. The instruments were used, namely interview guides, observation guides, data cards, as well as voice recorders, and cameras. The results of this study show (1) the process of writing scientific papers on extracurricular KIR at Undiksha High School Laboratory, which includes (a) giving KIR basic material, (b) practicing writing scientific papers, and (c) presentation exercise. (2) The use of language in students scientific works were found language errors include (a) spelling and (b) sentences. 3) The correlation of coaching relationship with the use of language in writing scientific papers.
\end{abstract}

Keywords: coaching, extracurriculars KIR 


\section{PENDAHULUAN}

$\begin{array}{cr}\text { Kegiatan } & \text { ekstrakurikuler } \\ \text { merupakan kegiatan } & \text { pembinaan }\end{array}$ kesiswaan yang dilaksanakan di luar kegiatan intrakurikuler. Hal tersebut telah diamanatkan dalam Permendiknas No. 39 tahun 2008 tentang pembinaan kesiswaan pasal 3 ayat 1. Depdikbud (dalam Saputra, 1998: 5) menyatakan bahwa ekstrakurikuler adalah kegiatan di luar jam pelajaran sekolah biasa, yang dilakukan di sekolah atau di luar sekolah dengan tujuan untuk memperluas pengetahuan siswa, mengenai hubungan antar mata pelajaran, menyalurkan bakat dan minat, serta melengkapi pembinaan manusia seutuhnya. Selain dapat dijadikan wadah untuk menyalurkan minat dan bakat siswa, kegiatan ekstrakurikuler diharapkan juga mampu memberikan life skill (kecakapan hidup) kepada siswa setelah selesai mengikuti kegiatan tersebut. Saputra (1998) menguatkan bahwa kegunaan fungsional dalam mengembangkan program ekstrakurikuler, yakni menyiapkan anak menjadi orang yang bertanggung jawab, (2) menemukan dan mengembangkan minat dan bakat pribadi, serta (3) menyiapkan dan mengarahkan pada suatu spesialisasi. Beragam jenis kegiatan ekstrakurikuler dapat dikembangkan oleh pihak sekolah untuk menyalurkan minat dan bakat peserta didik. Salah satu diantaranya adalah ekstrakurikuler karya ilmiah remaja kemudian disingkat KIR.

Karya ilmiah remaja adalah karya ilmiah yang ditulis atau dikerjakan oleh kalangan remaja. Karya ilmiah ditulis dengan mengikuti kaidah-kaidah ilmiah. Santoso (2014) mengemukakan bahwa kegiatan ekstrakurikuler karya IImiah remaja (KIR) adalah kegiatan yang dilakukan oleh kelompok remaja untuk melakukan serangkaian kegiatan yang menghasilkan suatu hasil yang disebut karya ilmiah. Karya ilmiah mempunyai arti sebagai suatu karya yang dihasilkan melalui cara berpikir ilmiah yang sesuai dengan kaidah penalaran yang logis, sistematis, rasional dan ada terdapat koherensi antar bagian-bagiannya.

\begin{tabular}{ccc}
\multicolumn{2}{c}{ Ekstrakurikuler } & KIR adalah suatu \\
kegiatan & ekstrakurikuler & yang
\end{tabular} dilaksanakan di tingkatan SLTP, SMU, SMK, Madrasah bahkan Pondok Pesantren. Ekstrakurikuler KIR ini merupakan suatu organisasi yang sifatnya terbuka bagi para remaja yang ingin mengembangkan kreativitas dan ilmu pengetahuannya dalam bidang penulisan karya ilmiah. Kegiatan ekstrakurikuler KIR di sekolah sangat berperan penting dalam mengoptimalkan peran sekolah sebagai lembaga pendidikan dan pengembangan bakat. Melalui kegiatan ekstrakurikuler $\mathrm{KIR}$, siswa dapat mengambangkan minat dan bakatnya dalam bidang penulisan karya ilmiah dan mengikuti kompetisi atau lomba karya tulis ilmiah dalam berbagai tingkat.

Keterampilan menulis hingga saat ini masih dipandang sebagai keterampilan yang paling sulit dibandingkan keterampilan berbahasa lainnya. Oleh karena itu, menulis karya ilmiah juga dipandang sulit. Hal ini terlihat dari sedikitnya jumlah siswa yang mengikuti ekstrakurikuler KIR. Siswa lebih memilih mengikuti ekstrakurikuler yang lain, seperti ekstakurikuler musik, basket, dan yang lainnya. Meskipun penulisan karya ilmiah dipandang sulit, di sejumlah sekolah tetap dikembangkan ekstrakurikuler KIR. Selain sebagai tempat penyaluran bakat dan minat, melalui ekstrakurikuler KIR ini juga akan dapat menumbuhkan sikap ilmiah, berpikir kritis, sikap ingin tahu, sikap objektif, sikap terbuka, dan sikap berani mempertahankan kebenaran yang diwujudkan dengan membela fakta atas hasil penelitian. Selain itu, masih maraknya perlombaan-perlombaan penulisan karya ilmiah sebagai bentuk apresiasi bagi siswa yang gemar menulis, khususnya menulis karya ilmiah.

Menulis karya ilmiah tergolong dalam salah satu keterampilan berbahasa, yakni keterampilan menulis. Keterampilan menulis karya ilmiah ini merupakan salah satu keterampilan yang penting untuk dikuasai oleh siswa. Pentingnya keterampilan menulis karya ilmiah terlihat dari program menulis karya ilmiah yang ternyata berkaitan dengan kurikulum bahasa Indonesia yang terlihat pada silabus bahasa Indonesia kelas $\mathrm{XI}$, 
dengan Kompetensi Dasar "Mengonstruksi sebuah karya ilmiah dengan memperhatikan isi, sistematika, dan kebahasaan". Jadi, untuk dapat mencapai tujuan pembelajaran yang diinginkan, siswa harus menguasai penulisan karya ilmiah.

Dalam menulis karya ilmiah dibutuhkan bahasa yang baik dan benar yang sesuai dengan PUEBI karena karya ilmiah merupakan sumber ilmu yang akan dipakai sebagai referensi bagi penulisan karya yang lain. Jika sebuah karya ilmiah menggunakan bahasa yang tidak sesuai dengan ketentuan yang berlaku, ditakutkan akan terjadi kesalahan atau banyak penafsiran pada tiap-tiap orang. Untuk mengantisipasi hal tersebut, dibutuhkan bahasa yang baik dan benar sesuai dengan kaidah yang berlaku. Berangkat dari hal tersebut, dilaksanakanlah penelitian terkait penggunaan bahasa dalam karya ilmiah siswa. Penelitian ini dilakukan untuk mengetahui kesesuaian penggunaan bahasa dengan kaidah bahasa ilmiah yang berlaku.

Dalam kegiatan ekstrakurikuler, kehadiran guru pembina sangat penting. Hal ini dikarenakan oleh pembinalah yang akan mengarahkan, membimbing, dan memfasilitasi para siswa yang mengikuti ekstrakurikuler. Dalam kegiatan ekstrakurikuler, harus memiliki guru pembina. Guru pembina bisa dari pihak sekolah maupun dari luar sekolah. Namun, biasanya guru pembina berasal dari pihak sekolah yang diberikan wewenang oleh kepala sekolah untuk membina ekstrakurikuler tertentu. Suryosubroto (2002) mengemukakan bahwa guru pembina ektrakurikuler adalah guru atau petugas khusus yang ditunjuk oleh kepala sekolah untuk membina kegiatan ekstrakurikuler yang berfungsi sebagai pemberi pengarahan dan pembinaan kepada siswa agar kegiatan ekstrakurikuler tersebut berjalan dengan tidak mengganggu ataupun merugikan aktivitas akademis. Tugas seorang guru pembina ekstrakurikuler adalah membina siswa dalam upaya mengembangkan potensi yang dimiliki. Membina dalam Kamus Besar Bahasa Indonesia (2011) berarti membangun, mendirikan. Oleh karena itu, pembinaan dapat diartikan sebagai sebuah tindakan, sebuah cara, proses pembaharuan, atau proses untuk menyempurnakan. Dalam hal ini, orang yang disempurnakan adalah orang yang dibina agar menjadi orang yang lebih bermanfaat dari sebelumnya. Jadi, pembina merupakan salah satu faktor penentu keberhasilan kegiatan ekstrakurikuler. Pembina ekstrakurikuler KIR merupakan guru pengajar mata pelajaran geografi. Namun dalam memberikan pembinaan penggunaan bahasa, pembina berkolaborasi dengan guru bahasa Indonesia. Berangkat dari hal tersebut, dilaksanakanlah penelitian terkait pembinaan dalam ekstrakurikuler KIR untuk melihat pembinaan yang berfokus pada pembinaan penggunaan bahasa.

Salah satu sekolah yang aktif melaksanakan kegiatan ekstrakurikuler KIR adalah SMA Laboratorium Undiksha. Para siswa di SMA Laboratorium Undiksha juga memiliki prestasi baik dalam menulis serta mempunyai antusiasme tinggi terhadap keterampilan menulis. Adanya salah satu ekstrakurikuler, yaitu KIR yang memberikan wadah bagi para siswa yang gemar menulis karya ilmiah sehingga membuat keterampilan menulis menjadi tumbuh dengan baik. Selain aktif dilaksanakan, ekstrakurikuler KIR di SMA Laboratorium Undiksha juga sering mendulang prestasi.

Saat melakukan observasi awal, pembina KIR SMA Laboratorium Undiksha, Kadek Ryan Surya Negara, S.Pd., M.Si menceritakan bahwa setiap tahunnya siswa KIR selalu mengikuti lomba-lomba penulisan karya ilmiah di tingkat nasional. Contoh prestasi yang berhasil diraih oleh siswa KIR pada tahun 2017, yaitu berhasil meraih juara 1 LKTI se-Bali yang diselenggarakan oleh Fakultas Ekonomi Universitas Padang, juara $1 \mathrm{LKTI}$ tingkat SMA se-Bali, Jawa, Nusa Tenggara yang diselenggarakan oleh HMJ Manajemen Undiksha, Juara 1 dan 3 LKTI se-Jawa Timur, Nusa Tenggara yang diselenggarakan oleh HMJ Pendidikan Geografi Undiksha, dan juara 3 LKTI Tingkat Nasional yang 
diselenggarakan oleh Universitas Andalas Padang. Berdasarkan prestasi-prestasi yang berhasil diraih oleh siswa yang mengikuti ekstrakurikuler KIR di SMA Laboratorium Undiksha, dapat diasumsikan bahwa pembinaan yang berlangsung di sekolah ini berjalan dengan baik karena setiap anggota dapat mengembangkan minat dan bakatnya dalam bidang menulis karya ilmiah. Berdasarkan data tersebut, SMA Laboratorium Undiksha dapat dikatakan ideal menjadi subjek penelitian. Jadi, dalam penelitian ini, SMA Laboratorium Undiksha ditetapkan sebagai subjek penelitian. Berdasarkan hal tersebut, maka penelitian ini diberi judul "Pembinaan dan Penggunaan Bahasa dalam Menulis Karya IImiah pada EkstrakurikulerKarya IImiah Remaja (KIR) di SMA Laboratorium Undiksha".

Berhubungan dengan penelitian tersebut, terdapat beberapa penelitian sejenis yang pernah diteliti sebelumnya, yaitu pembinaan kegiatan ekstrakurikuler menulis karya ilmiah yang dilakukan oleh Palupi pada tahun 2017 dengan penelitiannya yang berjudul "Pelaksanaan Pembinaan Kegiatan Ekstrakurikuler Menulis Karya IImiah Siswa SMA Negeri 6 Yogyakarta". Kemudian penelitian yang dilakukan oleh Uswati pada tahun 2015 dengan penelitiannya yang berjudul "Penggunaan Bahasa Ilmiah pada Penulisan Skripsi: Problematika dan Alternatif Solusinya (Studi Kasus Mahasiswa Jurusan Pendidikan Agama Islam lain Syekh Nurjati Cirebon)". Selanjutnya, penelitian yang dilakukan oleh Hidayati pada tahun 2016 yang berjudul "Pengaruh Kegiatan Ekstrakurikuler Kelompok Ilmiah Remaja (KIR) terhadap Keterampilan Proses Sains dan Sikap IImiah Siswa Man Berebes I". Terakhir penelitian yang dilakukan oleh Wulandari pada tahun 2017 yang berjudul "Pembinaan Kegiatan Ekstrakurikuler Karya Tulis IImiah (KTI) Bidang IPS di MTs Negeri Batu".

Keempat penelitian sejenis di atas memiliki persamaan dan perbedaan dengan penelitian yang dilakukan. Persamaan tersebut terlihat dari objek yang diteliti, yaitu sama-sama mengkaji pembinaan dalam menulis karya ilmiah dan penggunaan bahasa dalam karya ilmiah, sedangkan perbedaannya terdapat pada subjek, masalah, dan tujuan penelitian.

Berdasarkan pemaparan masalah di atas, Penelitian ini mengkaji tentang, (1) bagaimana proses pembinaan menulis karya ilmiah pada ekstrakurikuler karya ilmiah remaja (KIR) di SMA Laboratorium Undiksha,(2) bagaimana penggunaan bahasa dalam karya ilmiah siswa pada ekstrakurikuler karya ilmiah remaja (KIR) di SMA Laboratorium Undiksha, (3) apakah pembinaan menulis karya ilmiah berkaitan dengan penggunaan bahasa dalam karya ilmiah siswa pada ekstrakurikuler karya ilmiah remaja (KIR) di SMA Laboratorium Undiksha.

Sejalan dengan rumusan masalah yang telah diuraikan di atas, tujuan penelitian ini adalah untuk mendeskripsikan proses pembinaan menulis karya ilmiah dalam ekstrakurikuler karya ilmiah remaja (KIR) di SMA Laboratorium Undiksha, mendeskripsikan penggunaan bahasa dalam karya ilmiah siswa pada ekstrakurikuler karya ilmiah remaja (KIR) di SMA Laboratorium Undiksha, dan untuk mendeskripsikan keterkaitan pembinaan menulis karya ilmiah dengan penggunaan bahasa dalam karya ilmiah siswa pada ekstrakurikuler karya ilmiah remaja (KIR) di SMA Laboratorium Undiksha. Hasil dari penelitian ini diharapkan memberikan manfaat bagi sekolah, guru, pembina ekstrakurikuler KIR, dan siswa.

\section{METODE PENELITIAN}

Penelitian ini menggunakan ancangan deskriptif kualitatif. Ancangan penelitian deskriptif kualitatif ini bertujuan untuk menggambarkan sesuatu sebagai mana adanya dengan menggunakan katakata. Subjek dalam penelitian ini adalah pembina dan anggota ekstrakurikuler KIR di SMA Laboratorium Undiksha serta hasil karya tulis ilmiah siswa. Objek penelitian ini adalah proses pembinaan keterampilan menulis karya ilmiah, penggunaan bahasa dalam karya ilmiah siswa, serta keterkaitan antara pembinaan dan 
penggunaan bahasa dalam menulis karya ilmiah.

Metode pengumpulan data yang digunakan dalam penelitian ini yaitu observasi, wawancara, dan dokumentasi. Observasi yang digunakan adalah observasi nonpartisipan. Metode wawancara yang digunakan dalam penelitian ini adalah wawancara tidak terstruktur. Metode dokumentasi dipilih karena penelitian ini meneliti dokumen tertulis berupa hasil karya tulis ilmiah siswa.Instrumen penelitian yang digunakan dalam penelitian ini adalah alat perekam suara, kamera untuk mengambil gambar proses kegiatan pembinaan menulis karya ilmiah, pedoman wawancara untuk mewawancarai pembina, pedoman observasi sebagai pedoman dalam mengamati proses kegiatan pembinaan menulis karya ilmiah pada ekstrakurikuler KIR di SMA Laboratorium Undiksha, catatan lapangan berupa kertas atau buku catatan untuk mencatat hasil observasi dan hasil wawancara, serta kartu data yang digunakan untuk mencatat kutipan-kutipan data dalam karya tulis ilmiah siswa.

Dalam melakukan penelitian ini, data kualitatif yang telah diperoleh dianalisis secara deskriptif kualitatif.Kegiatan analisis deskriptif kualitatif meliputi reduksi data, deskripsi data, identifikasi data, klasifikasi data, penyajian data, dan simpulan.

Reduksi data dilakukan dengan cara memilah dan meimilih data sesuai unsur yang diteliti. Deskripsi data dilakukan dengan menggambarkan dan menguraikan data. Identifikasi data dilakukan dengan mengisi kriteria yang bertujuan mengenali data. Klasifikasi data dilakukan dengan menyusun kelompok data sesuai kategori. Penyajian data dilakukan untuk menunjukkan kondisi alamiah data. Terakhir adalah penarikan simpulan yang dilakukan dengan menjawab semua rumusan masalah.

\section{HASIL DAN PEMBAHASAN Hasil Penelitian}

Proses pembinaan menulis karya ilmiah pada ekstrakurikuler KIR di SMA Laboratorium Undiksha dapat dirinci dalam dua hal yaitu perencanaan dan proses pembinaan. Pembina ekstrakurikuler KIR di SMA Laboratorium Undiksha menyusun perencanaan kegiatan ekstrakurikuler KIR di SMA Laboratorium Undiksha dalam bentuk program kerja. Program kerja disusun berdasarkan waktu sehingga terdapat program kerja semester ganjil dan program kerja semester genap. Berdasarkan program kerja semester ganjil, pembina lebih memfokuskan pada pemberian materi dasar karya ilmiah dan latihan menulis karya ilmiah. Materi dasar karya ilmiah tersebut meliputi pengenalan bagian-bagian karya ilmiah. Setelah melakukan pembinaan materi, siswa kemudian berlatih menulis karya ilmiah. Urain program kerja semester genap meliputi latihan membuat salindia (power point) dari naskah karya tulis ilmiah, latihan presentasi, dan persiapan lomba. Dalam setiap kegiatan, pembina selalu memanfaatkan media sebagai upaya untuk membantu pembina dalam menyampaikan pengetahuan terkait kegiatan KIR yang sedang dilaksanakan. Salindia dan speaker merupakan media dan alat yang umum digunakan saat siswa berlatih presentasi.

Fokus pembinaan meliputi pemberian materi karya ilmiah, latihan menulis karya ilmiah, pembinaan penggunaan bahasa, dan komunikasi ilmiah. Pembinaan penggunaan bahasa dintergrasikan ketika siswa berlatih menulis karya ilmiah dan juga ketika siswa melaksanakan kominikasi ilmiah dalam bentuk presentasi. Oleh karena itu, untuk mengambarkan proses pembinaan menulis karya ilmiah yang didasari pada fokus pembinaan, diuraikan berdasarkan jenis-jenis kegiatan yang dilaksanakan, yaitu pemberian materi dasar, menulis karya ilmiah, dan berlatih presentasi.

Pemberian materi dasar karya ilmiah mengenai bagian-bagain karya ilmiah dilaksanakan pada awal kegiatan ekstrakurikuler. Materi menuliskan karya ilmiah bersumber dari buku yang diberikan OPSI (Olimpiade Penelitian Siswa Indonesia) dan juga dari sejumlah makalah serta artikel. Pembina menyampaikan materi dalam bentuk 
power point. Untuk memudahkan siswa memahami materi yang disampaikan oleh pembina mengenai bagian-bagian karya ilmiah, pembina memberikan contoh karya ilmiah dari anggota ekstrakurikuler KIR yang terdahulu. Karya ilmiah tersebut dijadikan sebagai media pengenalan karya ilmiah. Oleh karena itu, dalam memberikan materi pembina menggunakan metode ceramah dan metode pemodelan.

Kegiatan menulis karya ilmiah dilakukan setelah seluruh materi selesai disampaikan oleh pembina. Karya ilmiah dalam ekstrakurikuler KIR SMA Laboratorium Undiksha berupa laporan hasil penelitian. Menulis karya ilmiah dilakukan secara bertahap. Tahapan tersebut meliputi tahap persiapan, tahap penulisan, dan tahap penyuntingan/pengeditan. Pada tahap persiapan, kegiatan yang dilakukan adalah penentuan topik penelitia dan mebuat kerangka laporan. Pada tahap penulisan, siswa berlatih dibimbing oleh pembina. Pada tahap penyuntingan, siswa memperbaiki kesalahan-kesalahan yang terdapat dalam laporan penelitian mereka setelah diperiksa oleh pembina. Laporan hasil penelitian yang telah selesai dikerjakan oleh siswa kemudian diserahkan kepada pembina untuk diperiksa. Setelah siswa menyerahkan laporan hasil penelitian, pembina menandai kesalahan-kesalahan penggunaan bahasa kemudian siswa melakukan pengeditan untuk memperbaiki kesalahan-kesalahan penggunaan bahasa dalam karya ilmiah siswa. Oleh karena itu, pembinaan penggunaan bahasa dilakukan dengan mengintegrasikannya dalam kegiatan menulis karya ilmiah. Pada akhir pelasanaan pembinaan, pembina melakukan evaluasi terhadap proses kegiatan ekstrakurikuler pada pertemuan tersebut.

Siswa selesai menulis laporan hasil penelitian dan telah melakukan proses penyuntingan, kegiatan selanjutnya adalah berlatih untuk mempresentasikan laporan hasil penelitian yang telah dikerjakan dalam bentuk power point. Namun, sebelum siswa berlatih presentasi, pembina terlebih dahulu memberikan strategi membuat power point. Setelah siswa selesai membuat power point dari naskah karya tulis yang telah dibuat, langkah selanjutnya pembina memberikan contoh kepada siswa terkait cara presentasi yang baik. Latihan presentasi ini dilakukan setiap siswa mengahasilkan laporan hasil penelitian. Latihan presentasi ini dilakukan untuk mempersiapkan siswa mengikuti lomba karya tulis ilmiah dan sebagai nilai tugas siswa. Pembinaan penggunaan bahasa juga dilakukan pembina saat kegiatan presentasi. Pembina akan memperbaiki kesalahan-kesalahan penggunaan bahasa lisan siswa ketika berlatih presentasi. Pembina menyatakan bahwa sebelum siswa mendapat pembina, siswa masih sering menggunakan bahasa yang tidak baku saat berpresentasi. Namun, semakin sering siswa dilatih untuk berpresentasi dengan bahasa yang baku dan formal, siswa menjadi terbiasa untuk menyampikan pendapatnya dengan bahasa yang baku dan formal.

$$
\text { Data mengenai penggunaan }
$$

bahasa dalam karya ilmiah siswa diperoleh dengan metode dokumentasi. Data dalam penelitian ini diperoleh dari 3 karya ilmiah. Analisis ini dilakukan untuk melihat penggunaan bahasa dalam karya ilmiah siswa berdasarkan kaidah bahasa ilmiah yang berlaku. Analisis dilakukan dengan sistematis mulai dari abstrak hingga simpulan dan saran. Setelah menganalisis 3 karya ilmiah ditemukan kesalahan atau ketidaksesuaian dengan prinsip-prinsip bahasa ilmiah, seperti kesalahan ejaan, kesalahan penyusunan kalimat, kalimat pleonastis, dan kalimat yang kurang logis. Oleh karena itu hasil analisis disajikan berdasarkan jenis kesalahan yaitu kesalahan ejaan dan kesalahan pada kalimat. Adapun data jenis kesalahan penggunaan bahasa pada karya ilmiah siswa disajikan pada tabel berikut ini.

Tabel 1.1 Analisis Jenis Kesalahan

\begin{tabular}{|c|c|c|c|}
\hline \multirow{2}{*}{ No } & \multirow{2}{*}{$\begin{array}{l}\text { Karya } \\
\text { Ilmiah }\end{array}$} & \multicolumn{2}{|c|}{ Jenis Kesalahan } \\
\cline { 3 - 4 } & Ejaan & Kalimat \\
\hline 1 & Kl.1 & 2 & 1 \\
\hline 2 & Kl.2 & 3 & 3 \\
\hline 3 & Kl.3 & - & 4 \\
\hline
\end{tabular}




\begin{tabular}{|c|c|c|}
\hline Jumlah & 5 & 8 \\
\hline Berdasarkan tabel & $1.1, \quad$ secara
\end{tabular}

keseluruhan dari 3 karya ilmiah yang dianalisis ditemukan 5 kesalahan ejaan dan 8 kesalahan kalimat. Kesalahan ejaan meliputi kesalahan pemakain huruf kapital dan kesalahan merangkai kata. Kesalahan kalimat meliputi kesalahan stuktur kalimat, kalimat kurang logis, dan kalimat pleonastis.

Kesalahan ejaan yang terdapat pada karya ilmiah tersebut meliputi kesalahan pemakaian huruf dan kesalahan merangkai kata. Penjabaran kesalahan tiap-tiap jenis ejaan akan dijabarkan pada tabel berikut.

Tabel 1.2 Analisis Kesalahan Ejaan

\begin{tabular}{|c|c|c|c|}
\hline \multirow[b]{2}{*}{ No } & \multirow{2}{*}{$\begin{array}{l}\text { Karya } \\
\text { Ilmiah }\end{array}$} & \multicolumn{2}{|c|}{ Kesalahan Ejaan } \\
\hline & & $\begin{array}{c}\text { Pemakaian } \\
\text { Huruf }\end{array}$ & $\begin{array}{c}\text { Merangkai } \\
\text { Kata }\end{array}$ \\
\hline 1 & KI.1 & 1 & 1 \\
\hline 2 & $\mathrm{KI} .2$ & 3 & - \\
\hline 3 & KI.3 & - & - \\
\hline \multicolumn{2}{|c|}{ Jumlah } & 4 & 1 \\
\hline
\end{tabular}

Berdasarkan tabel 1.2, secara keseluruhan ditemukan kesalahan 5 jenis kesalahan ejaan yang meliputi kesalahan pemakaian huruf dan keslaahan merangkai kata. Kesalahan pemakaian huruf lebih banyak ditemukan dari pada kesalahan merangkai kata. Ditemukan 4 kesalahan pemakaian huruf dan 1 kesalahan merangkai kata dari 3 karya ilmiah yang dianalisis.

Selanjutnya, penjabaran kesalahan kalimat berdasarkan jenis kesalahannya akan dijabarkan pada tabel berikut.

\section{Tabel 1.3 Analisis Kesalahan Kalimat}

\begin{tabular}{|c|c|c|c|}
\hline \multirow[b]{2}{*}{ No } & \multirow{2}{*}{$\begin{array}{l}\text { Karya } \\
\text { IImiah }\end{array}$} & \multicolumn{2}{|c|}{ Kesalahan Ejaan } \\
\hline & & $\begin{array}{c}\text { Pemakaian } \\
\text { Huruf }\end{array}$ & $\begin{array}{c}\text { Merangkai } \\
\text { Kata }\end{array}$ \\
\hline 1 & KI.1 & 1 & 1 \\
\hline 2 & KI.2 & 3 & - \\
\hline 3 & KI.3 & - & - \\
\hline \multicolumn{2}{|c|}{ Jumlah } & 4 & 1 \\
\hline
\end{tabular}

keseluruhan ditemukan 9 kesalahan kalimat. kesalahan tersebut meliputi kesalahan struktur kalimat, kalimat tidak logis, dan kalimat pleonastis. Kesalahan sktuktur kalimat terjadi karena tidak jelasnya usur-unsur pembangun kalimat dalam kalimat tersebut. Kesalahan akibat kalimat yang tidak logis ditemukan 2 kalimat dan kesalahan kalimat pleonastis ditemukan 1 kalimat dari 3 karya ilmiah siswa yang dianalisis.

Berdasarkan data-data tersebut, dapat disimpulkan bahwa masih ditemukannya kesalahan-kesalahan penggunaan bahasa. Penulis haruslah menguasai kaidah penulisan karya ilmiah. Kaidah penulisan karya ilmiah secara umum dapat dibahas dari penggunaan bahasanya. Maka, dalam proses menulis perlu memperhatikan pengetahuan struktur bahasa yang meliputi diksi (pilihan kata), kalimat, dan paragraf.

Untuk melihat keterkaitan pembinaan dan penggunaan bahasa pada ektrakurikuler KIR di SMA Labaoratorium Undiksha digunakan metode observasi dan wawancara untuk mengumpulkan data.

Pembina menyatakan saat awal siswa mengikuti ekstrakurikuler KIR, siswa diberikan tugas membuat karya ilmiah untuk melihat kemampuan siswa dalam menulis karya ilmiah dan untuk melihat kemampuan siswa dalam penggunaan bahasa. Dari karya ilmiah tersebut, pembina menemukan banyak kesalahan bahasa. Saat awal mengikuti ekstrakurikuler KIR, siswa belum mengetahui kaidah bahasa ilmiah sehingga banyak ditemukan kesalahan dalam penggunaan bahasa. Kesalahan penggunaan bahasa juga ditemukan oleh pembina dalam bahasa lisan siswa pada awal berlatih presentasi. Seluruh siswa yang diwawancarai menyatakan bahwa mereka belum mengetahui kaidah bahasa ilmiah sebelum mengikuti ektrakurikuler.

Berdasarkan hasil wawancara,
seluruh siswa yang mengikuti ekstrakurikuler KIR di SMA Laboratorium Undiksha juga menyatakan bahwa mereka mengalami kesulitan dalam menggunakan bahasa untuk menulis karya ilmiah sebelum mengikuti pembinaan ekstrakurikuler KIR.

Kesalahan-kesalahan penggunaan bahasa yang dilakukan oleh siswa terminimalisir setelah siswa mengikuti pembinaan ekstrakurikuler KIR. Dalam ekstrakurikuler KIR, pembina tidak memberikan pembinaan secara khusus 
mengenai penggunaan bahasa. Namun, pembinaan penggunaan bahasa dintegrasikan ketika siswa berlatih menulis karya ilmiah dan berlatih presentasi. Jika ditemukan kesalahan penggunaan bahasa dalam karya ilmiah, pembina langsung mengoreksi dan mengarahkan siswa untuk memperbaiki. Pembinaan penggunaan bahasa dilakukan oleh pembina untuk mengurangi kesalahan berbahasa lisan dan bahasa tulis siswa. Pembina menyatakan setelah pembinaan menulis karya ilmiah pada ekstakurikuler KIR dilakukan, kesalahan berbahasa siswa baik secara lisan maupun tulisan lebih berkurang. Berdasarkan hasil wawancara, seluruh siswa yang mengikuti ekstrakurikuler KIR di SMA Laboratorium Undiksha juga menyatakan bahwa lebih mudah menulis karya ilmiah yang sesuai dengan kaidah bahasa ilmaih setelah mengikuti ekstrakurikuler KIR. Melalui pembinaan yang dilakukan, siswa mengetahui kaidah bahasa ilmiah. Dengan pengetahuan yang dimiliki siswa terhadap kaidah bahasa ilmiah, siswa akan lebih mudah untuk menulis kaya ilmiah.Hal ini dibuktikan dengan lebih sedikitnya ditemukan kesalahan penggunaan bahasa dalam karya ilmiah siswa.

\section{Pembahasan}

Proses pembinaan menulis karya ilmiah pada ekstrakurikuler KIR di SMA Laboratorium Undiksha dirinci menjadi dua hal yaitu perencanaan dan proses pembinaan. Dari hasil penelitian, temuan yang didapatkan oleh penulis yaitu program kerja yang disusun oleh pembina tidak diperbarui setiap tahunnya, dilakukannya kegiatan pembinaan penggunaan bahasa dalam menulis karya ilmiah, dan ditemukannya 3 fokus pembinaan yakni pemberian materi dasar KIR, berlatih menulis, dan berlatih presentasi.

Pembina menyusun perencanaan dalam bentuk program kerja. Program kerja tersebut dibagi menjadi dua, yaitu program kerja semester ganjil dan program kerja semester genap. Kedua program kerja tersebut digunakan sebagai patokan dalam melaksanakan kegiatan ekstrakurikuler KIR di SMA Laboratorium Undiksha. Proses pembinaan merupakan penerapan dari program kerja yang telah disusun. Hal ini senada dengan Harjanto (2005) yang menyatakan "Perencanaan berkaitan dengan penentuan apa yang akan dilakukan". Dengan demikian, tindakan pembina menyusun program kerja terlebih dahulu sangat tepat karena program kerja merupakan langkah awal yang wajib ada dalam sebuah organisasi atau kelompok agar kegiatan menjadi terarah. Namun, program kerja tidak pernah diperbaharui setiap tahunnya. Berdasarkan hasil penelitian yang didapatkan bahwa pembina tidak pernah memperbaharui program kerja karena kegiatan yang dilakukan setiap tahunnya sama.

Berdasarkan hasil penelitian, proses pembinaan ekstrakurikuler KIR meliputi pemberian materi dasar KIR dan praktek langsung. Praktek langsung diarahkan agar siswa dapat menerima pengalaman langsung mengenai penelitian. Hal tersebut tergambar dalam pendapat Suryosubroto (2002) yakni, "Kegiatan ekstrakurikuler bertujuan untuk memberikan pengalaman yang sesuai dengan hobi, bakat, minat, dan kemampuan peserta didik". Praktek langsung yang dilakukan adalah siswa berlatih menulis karya ilmiah dan berlatih presentasi.

Pemberian materi dasar KIR dilakukan pembina pada awal kegiatan ekstrakurikuler. Materi yang diberikan oleh pembina, bersumber atas buku yang diberikan OPSI, kumpulan jurnal, serta pengalaman pembina selama mengikut kegiatan ekstrakurikuler KIR saat duduk dibangku SMP dan SMA, pengalaman pembina saat mengikuti UKM PKM saat kuliah. Dalam menyampaikan materi, pembina memberikan siswa contoh karya ilmiah dari anggota KIR sebelumnya untuk mempermudah siswa memahami materi. Pembina menyampaikan materi dengan bahasa yang mudah dipahami oleh siswa. Pembina juga membimbing siswa dengan santai. Hal ini terlihat saat siswa ada yang bertanya. Saat siswa ada yang bertanya terkadang pembinalah yang mendekati siswa. Hal ini senada dengan Senjaya 
(2008) yang menyatakan "Sebagai fasilitator guru berperan memberikan pelayanan untuk memudahkan siswa dalam kegiatan proses pembelajaran". Setelah pemberian materi, pembina juga memberikan beberapa pertanyaan sebagai umpan balik untuk menguji pemahaman siswa terkait materi yang diberikan.

Kegiatan pembinaan pengunaan
bahasa dilakukan pembina dengan mengintegrasikannya dalam kegiatan menulis karya ilmiah dan presentasi. Kegiatan pembinaan penggunaan bahasa ini dilakukan pembina untuk meminimalisir kesalahan penggunaan bahasa dalam karya ilmiah siswa maupun dalam melakukan kegiatan komunikasi ilmiah dalam bentuk presentasi. Dalam proses pembinaan, pembina selalu membawa $\mathrm{KBBI}$ dan PUEBluntuk membina penggunaan bahasa.

Dari hasil penelitian, kegiatan menulis karya ilmiah dilakukan dengan bertahap. Tahapan tersebut meliputi tahap persiapan, tahap penulisan, dan tahap penyuntingan. Tahapan tersebut didasarkan pada kegiatan yang dilakukan. Pada tahap persiapan pembina menuntun siswa dalam mentukan topik penelitian dan membuat kerangka laporan. Dalam menentukan topik penelitian, pembina mengajak siswa untuk turun ke lapangan dan melihat permasalahan yang terjadi di lapangan. Pada kegiatan berlatih menulis, pembina mendampingi siswa untuk membantu siswa dalam menuangkan idenya. Tahap penyuntingan dilakukan untuk memperbaiki kesalahan penulisan maupun kesalahan penggunaan bahasa. Setelah siswa selesai menulis karya ilmiah dalam bentuk laporan hasil penelitian, pembina mengoreksi laporan tersebut. Jika pembina menemukan kesalahan penggunaan bahasa, pembina akan menggarisbawahi kesalahan tersebut dan mengarahkan siswa untuk memperbaikinya.

Kegiatan presentasi dilakukan pembina untuk mempersiapkan siswa dalam mengikuti lomba karya tulis ilmiah. Dalam kegiatan presentasi pembina menuntun siswa untuk menyampaikan pendapat dengan bahasa baku. Hal ini sejalan dengan yang disampaikan Sutomo (2007) "Presentasi adalah kegiatan aktif dimana seseorang pembicara menyampaikan dan mengomunikasikan ide serta informasi kepada sekelompok audiens". Dari pernyataan tersebut dapat diambil suatu kesimpulan jika presentasi merupakan kegiatan yang dilakukan secara aktif dengan melibatkan orang lain selain pembicara, sehingga pembicara harus mampu membuat presentasi menartik untuk didengarkan. Oleh karena itu dalam presentasi sangat penting memperhatikan bahasa yang digunakan. Dalam komunikasi ilmiah seperti mempresentasikan laporan hasil penelitian, haruslah menggunakan bahasa baku. Penggunaan bahasa juga merupakan salah satu aspek penilaian ketika siswa presentasi dalam lomba karya tulis ilmiah

Pembinaan menulis karya ilmiah pada ekstrakurikuler KIR sudah dilakukan secara maksimal. Hal ini dibuktikan oleh prestasi-prestasi yang berhasil diraih oleh siswa SMA Laboratorium Undiksha dalam lomba penulisan karya ilmiah. Siswa ekstrakurikuler KIR SMA Laboratorium Undiksha aktif mengikuti lomba-lomba penulisan karya ilmiah. Sebelum mengikuti lomba, pembina membimbing siswa untuk memaksimalkan kemampuan siswa dalam menulis karya ilmiah. Hal ini sesuai dengan yang disampaikan Thoha (2004), pembinaan adalah suatu tindakan, proses, hasil, atau pernyaataan yang lebih baik. Dalam hal ini menunjukan adanya kemajuan, peningkatan pertembuhan, evolusi atas berbagai kemungkinan, berkembang atau peningkatan atas suatu. Demikianlah proses pembinaan menulis karya ilmiah pada ekstrakurikuler karya ilmiah remaja (KIR) di SMA Laboratorium Undiksha. Berdasarkan pembahasan tersebut, dapat disimpulkan bahwa proses pembinaan kegiatan ekstrakurikuler karya ilmiah remaja (KIR) di SMA Laboratorium Undiksha dilakukan secara intensif dan terfokus. Hal ini dapat dilihat dari pembinaan yang dilakukan oleh pembina yang tidak hanya memperhatikan pada kemampuan menulis karya ilmiah saja tetapi juga memperhatikan aspek kebahasaan siswa. 
Berdasarkan hasil penelitian, didapatkan data penggunaan bahasa dalam karya ilmiah siswa masih ditemukan kesalahan penggunaan bahasa. Kesalahan-kesalahan yang terdapat dalam karya ilmiah siswa adalah kesalahan ejaan dan kesalahan penyusunan kalimat. Hal ini tentu bertentangan dengan definisi dari karya ilmiah yang disampaikan oleh Wibowo (2012:29) yakni, "Karya ilmiah didefinisikan sebagai tulisan yang didasari oleh hasil pengamatan, peninjauan, penelitian, dan perenungan dalam bidang keilmuan tertentu, disusun menurut metode tertentu dengan penulisan yang santun, baik, dan benar, atau berdasarkan kaidah baku ragam bahasa tulis". Berkorelasi dengan hal ini, maka bahasa akademik yang digunakan untuk menulis karya tulis ilmiah yang komunikatif adalah salah satu jenis tata permainan bahasa yang oleh karena itu juga memiliki aturanaturannya sendiri. Oleh karena itu dalam menulis karya ilmiah penggunaan bahasa harus sesuai dengan kaidah bahasa ilmiah agar pembaca dapat memahami dan menafsirkan sesuai dengan yang dimaksud penulis. Meskipun pembinaan penggunaan bahasa telah dilakukan oleh pembina, masih tetap ditemukan kesalahan penggunaan bahasa dalam karya ilmiah siswa. Hal ini tentu harus diperhatikan kembali oleh pembina.

Hasil penelitian ini terhadap penggunaan bahasa dalam karya ilmiah siswa menguatkan penelitian yang dilakukan Uswati (2015). Hasil penelitian Uswati menemukan adanya kesalahan penataan penalaran, kesalahan pemilihan kata, kesalahan penyusunan kalimat, kesalahan ejaan, dan kesalahan pembentukan kata pada skripsi mahasiswa Jurusan Pendidikan Agama Islam IAIN Syekh Nurjati Cirebon. Penelitian ini menemukan hal yang sama dengan penelitian Uswati. Pada penelitian ini ditemukan kesalahan ejaan dan kesalaha kalimat dalam karya ilmiah siswa yang mengikuti ekstrakurikuler KIR. Kesalahan ejaan meliputi kesalahan pemakaian huruf dan kesalahan merangkai kata sedangkan kesalahan kalimat meliputi kesalahan penyusunan struktur kalimat, kalimat tidak logis, dan kalimat pleonastis.

Berdasarkan hasil penelitian, dapat diamati bahwa pembinaan menulis karya ilmiah berkaitan dengan penggunaan bahasa dalam karya ilmiah siswa pada ekstrakurikuler karya ilmiah remaja (KIR) di SMA Laboratorium Undiksha. Hal ini tercermin dari pernyatan-pernyataan pembina dan siswa mengenai kemampuan dalam menggunakan bahasa sebelum pembinaan diberikan dan setelah pembinaan diberikan. Secara umum, siswa berpendapat lebih mudah menuliskan karya ilmiah yang sesuai dengan kaidah bahasa ilmiah setelah diberikan pembinaan penggunaan bahasa. Hal serupa juga disampaikan oleh pembina bahwa terjadi peningkatan kemampuan menulis karya ilmiah ditinjau dari penggunaan bahasa setelah diberikannya pembinaan penggunaan bahasa. Berdasarkan hasil wawancara terhadap pembina, pembina mengakui jika terjadi banyak kesalahan berbahasa dalam menulis karya ilmiah siswa sebelum diberikan pembinaan. Oleh karena itu, pembina memberikan pembinaan mengenai penggunaan bahasa yang diintegrasikan dalam kegiatan menulis karya ilmiah serta ketika presentasi.

Pembinaan penggunaan bahasa sangat penting dilakukan untuk meminimalir kesalahan berbahasa siswa. Hal ini sesuai dengan yang disampaikan Chaer (2013), pembinaan bahasa berarti hal/proses membina bahasa. Sasaran dari pembinaan bahasa adalah masyarakat pengguna bahasa. Pembinaan harus dilakukan (1) karena kemampuan berbahasa Indonesia masyarakat Indonesia sangat tidak memuaskan, (2) karena banyak orang Indonesia yang memiliki sikap negatif terhadap bahasa Indonesia sehingga mereka berbahasa Indonesia dengan prinsip "asal mengerti" tanpa memperhatikan kaidah-kaidah atau aturan bahasa yang benar dan bangga terhadap bahasa asing sehingga bahasa Indonesia mereka terinferensi kosakata bahasa asing (dalam hal ini bahasa inggris). Pengetahuan siswa mengenai kaidah bahasa ilmiah yang telah diberikan dalam pembinaan diterapkan oleh siswa 
dalam menulis karya ilmiah sehingga kesalahan penggunaan bahasa dalam karya ilmiah siswa dapat terminimalisir.

\section{SIMPULAN DAN SARAN}

Ada beberapa hal yang menjadi simpulan dalam penelitian ini. Pertama, fokus pembinaan yang dilaksanakan meliputi pemberian materi karya ilmiah, latihan menulis karya ilmiah, pembinaan penggunaan bahasa, dan komunikasi ilmiah. Pembinaan penggunaan bahasa diintegrasikan ketika siswa berlatih menulis karya ilmiah dan juga ketika siswa melaksanakan komunikasi ilmiah dalam bentuk presentasi.

Kedua, Setelah menganalisis 3 karya ilmiah siswa ditemukan kesalahan penggunaan bahasa. Kesalahan tersebut meliputi kesalahan ejaan dan kesalahan kalimat. Kesalahan ejaan meliputi 4 kesalahan pemakaian huruf dan 1 kesalahan merangkai kata. Kesalahan kalimat meliputi 6 kesalahan penyusunan struktur kalimat, 2 kalimat tidak logis, dan 1 kalimat pleonastis.

Ketiga, adanya keterkaitan antara pembinaan danpenggunaan bahasa dalam siswa menulis karya ilmiah. Melalui pembinaan penggunaan bahasa, siswa menjadi lebih mengetahui cara menuliskan karya ilmiah yang sesuai dengan kaidah bahasa ilmiah. Pengetahuan yang dimiliki oleh siswa itulah yang digunakan dalam menulis karya ilmiah sehingga kesalahan penggunaan bahasa dapat terminimalisir. Pembina mengakui sebelum diberikannya pembinaan penggunaan bahasa, kesalahan penggunaan bahasa dalam karya ilmiah siswa lebih banyak ditemui. Namun, setelah pembinaan diberikan kesalahan berbahasa siswa lebih terminimalisir.

Berdasarkan temuan-temuan dalam penelitian ini, terdapat beberapa saran yang dapat disampaikan. (1) Pembina harus lebih memperhatikan penggunaan bahasa siswa dalam menulis karya ilmiah agar tidak ditemukan lagi kesalahan penggunaan bahasa (2) penelitian ini menganalisis penggunaan bahasa sebelum pembinaan dilakukan maka untuk penelitian selanjutnya perlu diarahkan pada penelitian penggunaan bahasa dalam karya ilmiah siswa pada ekstrakurikuler KIR sebelum pembinaan penggunaan bahasa dilakukan. Hasil penelitian tersebut dapat dibandingkan dengan hasil penelitian ini untuk melihat keefektifan pembinaan yang berfokus pada aspek kebahasaan.

\section{DAFTAR PUSTAKA}

Chaer, Abdul. 2013. Pembinaan Bahasa Indonesia. Jakarta: Rineka Cipta.

Harjanto. 2005. Perencanaan Pengajaran. Jakarta: Rineka Cipta.

Santoso, Hari. 2014."Kontribusi Perpustakaan Sekolah dalam Menunjang Kegiatan Kelompok IImiah Remaja (KIR)". Tersedia pada library.um.ac.id/images/stories/pusta kawan/pdfhasan/kelompok\%20ilmia h\%20remaja\%20_kir_.pdf.(diakses tanggal 28 November 2017)

Senjaya, Wina. 2008. Strategi Pembelajaran, Berorientasi Standar Proses Pendidikan. Jakarta: Kencana Prenada Media Group.

Suryosubroto. 2002. Proses Belajar Mengajar di Sekolah. Jakarta: PT. Rineka.

Sutomo, Erwin. 2007. Presentasi Kreatif dengan Power Point. Jakarta: Andi Offset.

Thoha, Miftah. (2004). Pembinaan Organisasi Proses Diagnosa dan Interval. Jakarta : PT. Raja Grafindo Persada.

Tim Pusat Bahasa. 2011. Kamus Besar Bahasa Indonesia. Edisi ke-4. Jakarta:Gramedia Pustaka Utama.

Uswati, Tati Sri. 2015. Penggunaan Bahasa Ilmiah pada Penulisan Skripsi: Problematika dan Alternatif Solusinya (Studi Kasus Mahasiswa Jurusan Pendidikan Agama Islam lain Syekh Nurjati Cirebon). Artikel. Jurusan Pendidikan Bahasa dan Sastra Indonesia. Diunduh pada 12 April 2018.

Wibowo, Wahyu. 2012. Tata Permainan Bahasa Karya Tulis IImiah. Jakarta: Bumi Aksara. 